\title{
The Effectiveness Of Electronic Traffic Control Implementation In Reduce Motor Vehicle Accidents
}

\author{
Priyo Utomo*) and Lathifah Hanim ${ }^{* *}$ \\ *) Central Java High Court, E-mail: priyoutomo313@gmail.com \\ ${ }^{* *}$ Universitas Islam Sultan Agung (UNISSULA) Semarang
}

\begin{abstract}
The rapid growth of the number of motorized vehicles that is not matched by the legal culture of the people who use motorized vehicles often results in an increase in the number of accidents. Electronic based traffic control. However, the lack of facilities and infrastructure for the implementation of electronic traffic control has resulted in the ineffectiveness of electronic traffic control, this also happened in the Grobogan area. This paper aims to further analyze the effectiveness of the implementation of electronic traffic control, especially in the Grobogan area. The method in this writing is qualitative descriptive. Based on the analysis carried out, it can be seen that the implementation of Electronic Traffic supervision in the Grobogan area has not been effective this is due to inadequate facilities and infrastructure. Then the factor of community obedience to the traffic rules that apply in Gobogan.

Keywords: Effectiveness; Electronics; Traffic; Monitoring.
\end{abstract}

\section{Introduction}

Globalization in its development has had a negative impact on various sectors of life in Indonesia. The negative impact is essentially a threat to Indonesia's national security. The problems above show that as a result of globalization there has been a development of a spectrum of threats to national security which does not only cover the military sector but includes security in the political, economic, socio-cultural, and environmental fields. ${ }^{1}$

The transportation system is an important thing for a city, especially in big cities that have a lot of activity and many residents. In addition, the transportation system is crucial in determining the effectiveness of a city. There are so many cases of traffic violations on the highway by road users which tend to result in accidents and increasing traffic jams. ${ }^{2}$

The majority of traffic violations are in the form of violations in terms of markings, traffic signs and traffic control lights such as prohibition on stopping, parking in certain places, breaking through red lights, without vehicle documents and equipment, and others. These violations occur precisely during peak hours when community activity on the highway increases. The development of the number of motorized vehicles in Indonesia has increased rapidly along with the increase in motorized transportation equipment as well as an increase in traffic violations. It is this background that makes the police set up an E-ticket regulation

\footnotetext{
${ }^{1}$ Berry Buzan, Ole Waever, and Jaap de Wilde, Security A New Framework for Analysis, Lynne Rienner Publisher, United Kingdom, 1998, p. 8-9.

${ }^{2}$ A Annis Nurwianti, Gunarto, Sri Endah Wahyuningsih, "Implementasi Restoratif / Restorative Justice Dalam Penyelesaian Tindak Pidana Kecelakaan Lalu Lintas Yang Dilakukan Oleh Anak Di Polres Rembang”, Jurnal Hukum Khaira Ummah Vol. 12. No. 4 Desember 2017, December, 2017, p. 707-709.
} 
which is expected to assist in handling cases of traffic violations and illegal levies which have recently been rife along with the growth of transportation modes. Traffic violations cannot be ignored because most traffic accidents are caused by the human factor of road users who do not comply with traffic regulations. However, there are still causes other than human factors such as broken tires, failed brakes, potholes, traffic jams, high volume of vehicles passing through certain roads, road conditions, inadequate road infrastructure and others. ${ }^{3}$

Based on Act No. 8 of 1981 concerning the Criminal Procedure Code and Act No. 22 of 2009 concerning Road Traffic and Transportation, it is stated that the court together with the police and the prosecutor's office are institutions that organize traffic management cases. Traffic law enforcement is one of the activities of the traffic function which has a role so that laws and other regulations are obeyed by every road user, which are grouped into preventive and repressive efforts. ${ }^{4}$ One form of law enforcement in the field of repressive measures is the prosecution of traffic violations. Traffic violations can be carried out in an educative manner, namely by giving warnings and warnings in a sympathetic way to traffic violators, while juridically, prosecution is carried out by using a ticket and/or using a brief report / summary / minor crime or with an ordinary report. Article 272 of Act No. 22 of 2009 concerning Road Traffic and Transportation provides space for Police investigators and PPNS to carry out enforcement activities in the field of Traffic and Road Transportation by using electronic equipment. ${ }^{5}$

The electronic equipment in question is an incident recording device that can store information which can also be used as evidence in court. It was further explained that the prosecution of violations with electronic recording evidence is regulated in Government Regulation No. 80 of 2012. This is in line with the current situation and developments which are limited in the number of traffic police officers in the field in the context of traffic control and the creation of security, safety and order. , and smooth traffic. Therefore, the support and role of technology must be optimized, one of which is through traffic law enforcement with electronics (electronic recording/cameras). The use of electronics/cameras has become a must in the midst of various kinds of traffic violations that occur.

In the era of globalization, transportation is one of the basic and important needs. In traffic, people often ignore existing traffic signs, especially traffic signs at highway intersections. As is well known, to improve community discipline in traffic. Technological advances in the era of globalization have brought technological advances that can be applied in people's lives, one of which is in terms of traffic. The use of surveillance systems with CCTV (close circuit television) is a form of progress in today's traffic world. This includes the City of Purwodadi. This is Electronic Traffic Law Enforcement(ETLE).

\footnotetext{
${ }^{3}$ Muhar Muhar Junef, Perilaku Masyarakat Terhadap Operasi Bukti Pelanggaran (Tilang), E-Journal WIDYA Yustisia, Volume 1 Nomor 1 June 2014, p. 53.

${ }^{4}$ Malik AL-Ghazali, Restorative Justice Approach on The Under Age (Minors) Violator of The Traffic Case Accident (Laka) That Lead to Death in Polres Majalengka, Jurnal Daulat Hukum Volume 1 Issue 3 September 2018, p. 708-800.

${ }^{5}$ Iman Faturrahman dan Bambang Tri Bawono, Application of Restorative Justice to Solution of Traffic Accidents, Jurnal Daulat Hukum Volume 4 Issue 1, March 2021, p. 30-31.
} 
Technology is developing very fast as is happening today, which used to be to monitor traffic order only by government workers such as traffic police, but now there is a remote monitoring system to monitor traffic order and problems on the roads, especially crossroads using CCTV (close circuit television). ${ }^{6}$

The government also installs CCTV at all points of the area that are considered vulnerable. However, this cannot be said to be fully effective. The problem is the lack of knowledge and awareness of some Grobogan people related to traffic discipline and the lack of related facilities and infrastructure Electronic Traffic Law Enforcement (ETLE). So far, it's been a problem. ${ }^{7}$ This is shown by the number of traffic violations in Grobogan in 2020 of 891,525 violations. ${ }^{8}$ So it is necessary to discuss further regarding the effectiveness of electronic traffic control, especially in the Grobogan area.

\section{Research Methods}

Research in writing this research is descriptive qualitative. Descriptive research qualitative, is a research method that seeks to describe and interpret objects according to what they are, with the aim of systematically describing the facts and characteristics of the research object being studied appropriately. So that it can be analyzed further based on the data or materials obtained. ${ }^{9}$

\section{Result and Discussion}

\subsection{Current Implementation of Electronic Traffic Control}

In its development the implementation of Electronic Traffic Law Enforcement (E-TLE) using an electronic system involves several elements as well as facilities and infrastructure, namely, First, officers who involve the NCO who serve the ticketing unit at the Grobogan Police without having an office at the ETLE post as a backoffice, and 12 people who tasked with a pattern of 3 groups of 2 parts where each group is on duty for 12 hours to monitor, analyze, check databases, and input confirmation letter data; Second, Closed Circuit Television (CCTV) which is spread across several road points in Grobogan City. Of the 100 CCTV cameras that have been prepared, there are 23 CCTV cameras that have been installed and monitor and record traffic violations that occur; Third, computer, which is used to support the implementation of E-TLE, there are 6 (six) units that function as monitoring computers from CCTV connected to 23 camera points, playback for recording violations that have been monitored and computer inputting violation data into the system or web service for information and communication tickets. camera; Fourth, an application that supports the flow of

\footnotetext{
6 Lathifah Hanim, Engaruh Perkembangan Teknologi Informasi Terhadap Keabsahan Perjanjian Dalam Perdagangan Secara Elektronik (E-Commerce) Di Era Globalisasi, Jurnal Dinamika Hukum Vol. 11 Special Edition February 2011, p. 59-61.

7 Rully Trie Prasetyo, Umar Ma'ruf, and Anis Mashdurohatun, Tindak Pidana Korporasi Dalam Perspektif Kebijakan Formulasi Hukum Pidana, Jurnal Hukum Khaira Ummah Vol. 12. No. 4 December 2017, p. 729-730.

${ }^{8}$ AKP Sri Murtini, Personal Interview with Head of Traffic Police of the Grobogan Resort Police on May 20, 2021.

${ }^{9}$ Bambang Sunggono, 2006. Metodologi Penelitian Hukum, Jakarta : PT Grafindo Persada, p. 116.
} 
the mechanism for handling and resolving traffic violation cases resulting from the action of camera ticketing, a web service-based system that is integrated with the Regident Ranmor database, the system itself is divided into three, the first is for the public to provide confirmation related to the subject involved. be a violation, the second is for operators of related agencies that can be accessed on a limited basis and lastly for officers to enter data on violations as well as for officers to temporarily block the STNK of violating vehicles; and Fifth, the office that is used as a command center room for the Grobogan Police and for personnel who manned the personnel of the Grobogan Police. With the elements and facilities and infrastructure as above, the settlement of criminal cases of traffic violations has been carried out in several areas in Grobogan. The implementation is carried out by the Grobogan Police Station under the coordination of the Grobogan Police Traffic Directorate Sub-Directorate General by using facilities and infrastructure as well as established concepts or mechanisms. From this implementation, it was found that the application of traffic violation enforcement with electronic record evidence had a significant impact. This is evidenced by the discovery of various forms of traffic violations. The effectiveness of implementing the implementation of E-TLE (Electronic Traffic Law Enforcement) does not only provide benefits to the community, but also to the Indonesian National Police. Almost all developed countries have implemented an electronic ticket system and do not have to attend a trial in court. In other countries, the ticket is an administrative fine, not a crime, while in Indonesia the ticket is a criminal fine. ${ }^{10}$

\subsection{The Effectiveness of the Implementation of Electronic Traffic Control in Reducing Motor Vehicle Accidents}

Before explaining the effectiveness of the implementation of traffic control in reducing motor vehicle accidents that affect the effectiveness of electronic traffic control, it is necessary to first discuss Friedman's theory of the legal system.

Lawrence M. Friedman states that the law consists of components of structure, substance and culture. ${ }^{11}$

- The structural component is the institution created by the legal system with various functions in order to support the operation of the system. This component is possible to see how the legal system provides services for the cultivation of legal materials on a regular basis.

- The substantive component, which is the output of the legal system, in the form of regulations, decisions used by both the regulating and regulated parties.

- The cultural component, which consists of values, attitudes, perceptions, custom, ways of doing, ways of thinking, opinions that affect the workings of law by Lawrence M. Friedman is referred to as legal culture. This legal culture serves as a bridge that connects the rule of law with the legal behavior of all citizens.

\footnotetext{
10 AKP Muchamad Yogi, Personal Interview with Head of Traffic Police of Grobogan Regarding Electronic Traffic Control, Interview conducted on May 12, 2021.

${ }^{11}$ Esmi Warassih, Pranata Hukum Sebuah Telaah Sosiologis, (Semarang: Badan Penerbit Universitas Diponegoro, 2011), p. 28.
} 
Based on Friedman's thoughts above, it can be seen that the factors that influence the implementation of electronic traffic control today are influenced by: ${ }^{12}$

- Law Enforcement Factor

Law Enforcement Factors are the parties that form and apply the law. One of the keys to success in law enforcement is the mentality or personality of the law enforcers themselves. In the context of law enforcement by every law enforcement agency, justice and truth must be stated, felt, seen and actualized. ${ }^{13}$ In this case, law enforcers are enforcement officers who usually in carrying out their duties and functions there are errors in the input application that make officers lose track of violators. Thus, this problem becomes one of the important obstacles. If there is an input error, for example on the identity of the violator, it is certainly difficult to track the whereabouts of the violator.

- Facilities and Pre-Facilities Factor

Facilities and infrastructure factors based on CCTV contained in the Makassar Polrestabes Command Center room, there are several road markings that are not clear so that enforcement officers cannot take action on electronic ticketing.

- Community Factor

The community factor itself is one of the deficiency factors in the application of the Electronic Traffic Law Enforcement (E-TLE) system, in its development there are still many drivers or people who do not carry out the transfer process after making a motor vehicle purchase transaction, which results in a confirmed letter not arriving. to violators or current vehicle owners.

\subsection{The Effectiveness of Electronic Traffic Control in the Grobogan area}

Various factors and obstacles as described above also occur in the Grobogan area, but the most dominant factor is the lack of facilities and infrastructure. Until now, there has been no installation of CCTV cameras at accident-prone points in the Grobogan area according to Iptu Chandra Bayu as the Head of Traffic Accidents in the Grobogan area, from January to April 2021 there were 213 cases of traffic accidents in the Grobogan area. The factors causing the accident were the condition of the vehicle and the lack of obedience of traffic drivers to the applicable traffic rules. Bayu further stated that of this number, 58 of them were students. It is still dominated by the general public but students are also quite high. ${ }^{14}$

\section{Closing}

The implementation of Electronic Traffic supervision in the Grobogan area has not been effective this is due to inadequate facilities and infrastructure. Then the factor of community obedience to the traffic rules that apply in Gobogan. It is

\footnotetext{
12 AKP Muchamad Yogi, Personal Interview with Head of Traffic Police of Grobogan Regarding Electronic Traffic Control, Interview conducted on May 12, 2021.

${ }^{13}$ Arif Septria Hendra Saputra, Gunarto, dan Lathifah Hanim, Penerapan Restoratife Justice Sebagai Alternatif Penyelesaian Tindak Pidana Penganiayaan Di Satreskrim Polsek Lasem, Jurnal Daulat Hukum Vol. 1. No. 1 March 2018, p. 159.

${ }^{14}$ Iptu Chandra Bayu, Personal Interview with Head of Traffic and Traffic Police of Grobogan Police, interview conducted on 12 May 2021.
} 
necessary to develop and provide adequate facilities and infrastructure in carrying out electronic traffic control in the Grobogan area.

\section{References}

\section{Journal}

[1] Annis Nurwianti, Gunarto, Sri Endah Wahyuningsih, Implementasi Restoratif / Restorative Justice Dalam Penyelesaian Tindak Pidana Kecelakaan Lalu Lintas Yang Dilakukan Oleh Anak Di Polres Rembang, Jurnal Hukum Khaira Ummah Vol. 12. No. 4 December 2017

[2] Arif Septria Hendra Saputra, Gunarto, dan Lathifah Hanim, Penerapan Restoratife Justice Sebagai Alternatif Penyelesaian Tindak Pidana Penganiayaan Di Satreskrim Polsek Lasem, Jurnal Daulat Hukum Vol. 1. No. 1 March 2018

[3] Iman Faturrahman dan Bambang Tri Bawono, Application of Restorative Justice to Solution of Traffic Accidents, Jurnal Daulat Hukum Volume 4 Issue 1, March 2021

[4] Lathifah Hanim, Pengaruh Perkembangan Teknologi Informasi Terhadap Keabsahan Perjanjian Dalam Perdagangan Secara Elektronik (E-Commerce) Di Era Globalisasi, Jurnal Dinamika Hukum Vol. 11 Special Edition February 2011

[5] Malik AL-Ghazali, Restorative Justice Approach on The Under Age (Minors) Violator of The Traffic Case Accident (Laka) That Lead to Death in Polres Majalengka, Jurnal Daulat Hukum Volume 1 Issue 3 September 2018

[6] Muhar Junef, Perilaku Masyarakat Terhadap Operasi Bukti Pelanggaran (Tilang), E-Journal WIDYA Yustisia, Volume 1 Nomor 1 Juni 2014

[7] Rully Trie Prasetyo, Umar Ma'ruf, and Anis Mashdurohatun, Tindak Pidana Korporasi Dalam Perspektif Kebijakan Formulasi Hukum Pidana, Jurnal Hukum Khaira Ummah Vol. 12. No. 4 December 2017

\section{Book}

[1] Bambang Sunggono, 2006, Metodologi Penelitian Hukum, PT Grafindo Persada, Jakarta

[2] Berry Buzan, Ole Waever, and Jaap de Wilde, 1998, Security A New Framework for Analysis, Lynne Rienner Publisher, United Kingdom

[3] Esmi Warassih, 2011, Pranata Hukum Sebuah Telaah Sosiologis, Badan Penerbit Universitas Diponegoro, Semarang

\section{Interview}

[1] AKP Muchamad Yogi, Personal Interview with Head of Traffic Police of Grobogan Regarding Electronic Traffic Control, Interview conducted on 12 May 2021

[2] Iptu Chandra Bayu, Personal Interview with Head of Traffic and Traffic Police of Grobogan, interview conducted on 12 May 2021 